\title{
4 A Metacognitive Approach to Intercultural Learning in Language Teacher Education
}

\author{
Magne Dypedahl
}

\section{Introduction}

Metacognition - which can be described as knowledge of cognition, regulation of cognition and cognition about cognition-is recognised as a pillar of effective learning (see Bransford, Brown and Cocking 2000, 18; Flavell 2004,275 ). For that reason, metacognitive reflection is embedded in teacher education programmes all over the world, including those for language students. It is a means for teacher students to develop their capacities both as learners and as teachers of a foreign language. As Haukås (2018, this volume) points out, "in order to support students in their language learning, language teachers themselves must be metacognitively aware in several respects" (p. 25). One important aspect of this awareness is how language teacher students can best learn to be actively conscious of their knowledge and beliefs about the development of intercultural competence.

The aim of this chapter is to explore some general principles for designing courses in language teacher education that can enhance a metacognitive approach to intercultural learning. The courses in question may have the development of intercultural competence as the main learning goal or be more general language courses in which intercultural competence is one of many learning goals; for example, alongside literature or language proficiency. Although language teacher programmes will have to meet the requirements of national frameworks for higher education and institutional guidelines, much depends on course instructors, who are the main target group of the present chapter. Instructors can be regarded as key factors for intercultural learning for two reasons. First, they are in most cases the prime course designers with regard to syllabus, teaching and assessment. Second, their knowledge and beliefs about intercultural learning are likely to influence the teachers they educate.

A consistent metacognitive approach to intercultural learning requires a coherent course design. This entails consistency between (1) a metacognitive approach to the concept of intercultural competence, (2) the knowledge about intercultural communication presented to the students and (3) how intercultural competence is assessed. Accordingly, I will discuss central 
aspects of intercultural learning with a main focus on metacognitive reflection in language teacher education. The chapter is divided into four main sections following this introduction. The first section discusses a metacognitive approach to the concept of intercultural competence and models of intercultural competence. The next section provides examples of knowledge of intercultural communication that can be included in courses. The third section explores some teaching techniques for the development of metacognitive intercultural competence, whereas the last section discusses a metacognitive approach to the assessment of intercultural competence.

\section{The Concept of Intercultural Competence}

In this chapter, I have chosen the term "intercultural competence" to describe the aim of intercultural learning. However, the literature contains an abundance of synonyms and near-synonyms that refer to the same concept, such as "intercultural intelligence" (Peterson 2004), "intercultural sensitivity" (Bennett 1998), "intercultural communicative competence" (Byram 1997), "postcultural competence" (Jensen 2011, 47-8) and "critical cosmopolitanism" (Holliday 2011, 12), just to mention a few (see Fantini 2009, 457). Course instructors may want to choose a term they feel is consistent with their understanding of culture and the general philosophical underpinnings of the course. For example, the use of the term "critical cosmopolitism" is inspired by the need to place "the issue of culture firmly within a global political arena" (Holliday 2011, 13). Another possibility is to use the term "transnational competence" to indicate that the course represents a transnational paradigm, which, according to Risager, is "based on an awareness of linguistic and cultural complexity" (Risager 2007, 216). Nonetheless, "intercultural competence" seems to be the generally preferred term among intercultural experts (see Deardorff 2004, 170). This may change with time, but well-established terms do not generally have to be replaced because of changing paradigms. What will be needed in the case of moving from one paradigm to another is to provide a compatible definition of the concept and a description of how it is understood.

\section{Defining "Intercultural Competence"}

Before discussing the understanding and definition of "intercultural competence", there is no way to escape a discussion of the word "culture", which has been famously referred to as "one of the two or three most complicated words in the English language" (Williams 1983, 87). Clearly, the word can be used with very different meanings. A traditional understanding of "culture" typically revolves around behaviours, norms, beliefs and values that are shared by a group of people or the majority of people in a society. By the same token, "culture" could refer to a national culture, as is often seen in language education, for example, in discussing the use of a target language 
in a target culture. There are good reasons for maintaining this as one use of the word in language education. This means that certain behaviours, norms, beliefs and values are acknowledged as more dominant than others in a society.

Nevertheless, within a transnational paradigm, this understanding of culture cannot be transferred to the understanding of "intercultural communication". First of all, cultures do not communicate; people do. More importantly, however, many individuals do not share the dominant behaviours, norms, beliefs and values of their national culture. Or even if people generally do, there are many complementary sources of cultural influence that lead to considerable variation. Many of these sources, perhaps most, transcend national boundaries, such as impacts from popular culture. Although the use of "culture" within a transnational paradigm is not linked to national culture, communication is still closely intertwined with "culture". As Baker (2012) writes, "language, even used as a lingua franca, can never be culturally neutral" (64). While also acknowledging biological factors, there is no doubt that our mindsets and communication patterns are influenced by our surroundings or group memberships. This can be labelled "cultural impact". Since the sources of this impact are very complex and transnational, the approach to intercultural learning should reflect this. Consequently, the object of investigation is not only the impact of national belonging, but also the impact of group belonging in general.

For that reason, I define "intercultural competence" as "the ability to think and communicate appropriately with people who have different mindsets and/or communication patterns" (adapted from Dypedahl and Bøhn 2017, 14; see also Hammer, Bennett, and Wiseman 2003, 422). In addition to the act of communication, this definition includes the ability to think appropriately. This entails both the cognitive and metacognitive aspect of intercultural competence. Furthermore, the word "appropriate" refers both to getting any message across and the ability to maintain a good relationship, but I acknowledge that conceptualisations involving an evaluative expression such as "appropriate" are intrinsically problematic, as is the concept of "competence" (see Deardorff 2004, 25ff). On the other hand, definitions that seek to be more precise run the risk of becoming less comprehensible and less useful for pedagogical purposes.

\section{The Components of Intercultural Competence}

For course instructors, it is necessary to identify certain components of intercultural competence. Although there can be no definitive solution as to what these components should be, some work has been done on finding consensual aspects of intercultural competence. Deardorff (2004) used the interactive Delphi technique with a panel of 21 intercultural experts in three rounds to identify the most important components of intercultural competence. The top-rated components of intercultural competence were "Skills 
to analyze, interpret, \& relate", "Flexibility", "Cultural self-awareness and capacity for self-assessment", "Adaptability—adjustment to new cultural environment", "Tolerating and engaging ambiguity", "Deep knowledge and understanding of culture (one's own and others')", "Withholding judgment", "Skills to listen and observe", "Respect for other cultures" and "Cross-cultural empathy" (Deardorff 2004, 173). While scientific consensus within this field of study may not be an aim in itself, a certain degree of consensus building is very likely to make it easier for language educators and students to relate to intercultural learning.

\section{Exploring a Model for Metacognitive Intercultural Competence}

Although further work on consensual aspects of intercultural competence should be encouraged, several decades of scholarly work in the field have resulted in many models that can provide good ways of conceptualising this competence. According to some reviews, there are at least 30 comprehensive models and 300 similar constructs (see Leung, Ang, and Tan 2014, 491). However, as Van de Vijver and Leung (2009) point out, "[t]here is almost no empirical work in which the various models that have been proposed are compared and tested" (406). Although a diversity of models is not a problem as such, Spitzberg and Changnon (2009) argue that "there is a need to provide a parsimonious model that can successfully integrate such diversity" (45). In the meantime, course instructors will have to make some choices if models are to be included in the course.

In the context of language learning in Europe, Byram's (1997) model of intercultural communicative competence seems to have become somewhat of a gold standard. The model includes the categories savoirs, savoir s'engager, savoir comprendre, savoir apprendrelfaire and savoir être. Byram (1997) describes "savoirs" as the knowledge of self, others and of social processes of interaction. "Savoir s'engager" refers to political education and critical cultural awareness, which is explained as the ability to evaluate perspectives, practices and products of one's own and others' cultures (101). "Savoir comprendre" refers to skills to interpret and relate, whereas "savoir apprendre/faire" refers to skills of discovery and interaction. In other words, skills are divided into two categories. Finally, "savoir être", or attitudes, is described as relativising self and valuing others' values, beliefs and behaviours (34ff, 101).

In the United States, Fantini's (2014) model also seems to be relatively well known. Fantini distinguishes four dimensions of intercultural communicative competence: knowledge, positive attitudes/affect, skills and awareness. For the purpose of discussing metacognitive reflection, particularly the last component is interesting. According to Fantini (2014), '[a]wareness differs from knowledge in that it is always about the "self" vis-a-vis everything else in the world (other things, other people, other thoughts, etc.), and ultimately help to clarify what is deepest and most relevant to one's identity' 


\section{Magne Dypedahl}

(272). While both Fantini's and Byram's models can be used for metacognitive reflection as well, it can also be argued that they pay insufficient attention to metacognitive strategies (see Sercu 2004, 77). Further support for this point of view can be found in Lane (2009), who writes that:

true intercultural competence requires (at least) a heightened sense of self-awareness, an ability to self-assess, enhanced perceptive abilities, and a proclivity to reflect on experience. In other words, intercultural development requires concomitant metacognitive growth.

More arguments, and empirical evidence, for the importance of metacognition in intercultural learning can be found within the field of cross-cultural psychology (see Earley and Ang 2003; Earley, Ang, and Tan 2006; Klafehn, Banerjee, and Chiu 2008; Van Dyne, Ang, and Koh 2008). In this field, the concept of "cultural intelligence" is developed based on empirical research conducted to understand the success factors of international assignment (Shaffer and Miller 2008, 109). Factors that seem to have an impact include previous experience, self-efficacy, relational skills and cultural novelty. The concept of cultural intelligence can be subdivided into three loci: mental (both cognitive and metacognitive), motivational and behavioural. The category of "metacognitive intelligence" can be described as "an individual's cultural consciousness and awareness during interactions with those from different cultural backgrounds" (Van Dyne, Ang, and Koh 2008, 17).

In sum, there seem to be good reasons for developing models of intercultural competence that clearly identify metacognition as a central element. Figure 4.1 outlines such a model of intercultural competence inspired by Deardorff $(2006,2015)$. In this model, I label the metacognitive aspect of intercultural competence as "intercultural awareness" and define it as "the conscious monitoring and adjustment of one's own thinking and interaction with other people". This means that intercultural awareness in this context is defined as one component of intercultural competence and not as a synonym of intercultural competence, as often seems to be done.

\section{Central Components of the Model for Metacognitive Intercultural Competence}

In this case, a process model is chosen to underscore that intercultural learning is an eternal cycle of lifelong learning. Furthermore, as Sercu (2004) underlines, in the context of foreign language education, "intercultural competence' always implies 'communicative competence', and therefore always also has a linguistic, sociolinguistic and discourse component" (75). This is probably true for any context. Thus communicative competence and language competence is presented as a premise of intercultural competence along with certain attitudes and the willingness to get along with 


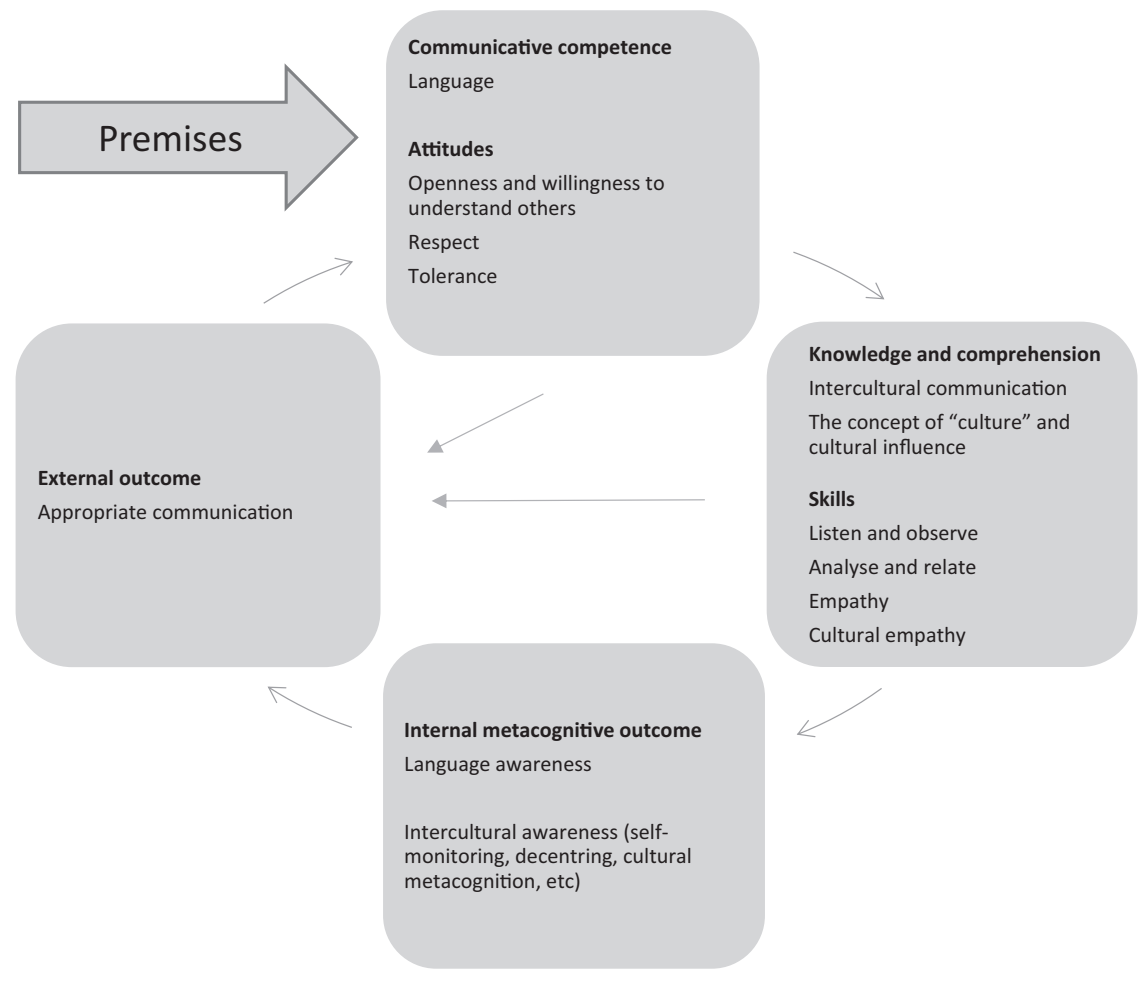

Figure 4.1 Framework for metacognitive intercultural learning, inspired by Deardorff 2006, 2015.

other people. Since the understanding of intercultural competence in this chapter does not require communication in a foreign language, "language competence" includes first languages. However, for foreign language education, it will obviously also include proficiency in the foreign language

There is an arrow directly from the premises to the external outcome, or appropriate communication. This is to indicate that people with communicative competence can succeed well in any context. Likewise, the arrow from the box to the right to the box to the left indicates that it is possible to bypass the internal metacognitive outcome. Obviously, it is possible to communicate appropriately without a high level of consciousness. However, this would not represent a high degree of metacognitive intercultural learning. This model is based on the belief that more intercultural competence will be developed by going full circle.

In this framework, the traditional components of knowledge, skills and attitudes are all included, but "attitudes" has been placed in the upper box to indicate that attitudes can be premises of intercultural competence as well 
as an outcome of the learning process. In the box to the right, "knowledge" includes knowledge about the concept of culture, cultural impact and intercultural communication (see section on the choice of content knowledge below). With regard to "skills", this can refer to cognitive activities, such as listening and observing, but also to other activities or abilities that can be both cognitive and metacognitive, such as analysing, relating, empathy and cultural empathy. As opposed to empathy, which is the ability to put oneself in someone's shoes, cultural empathy is not about particular individuals. It can be described as the ability to understand how growing up and living in other contexts may influence how people interpret the world.

The lower box focuses on metacognition, namely "language awareness" and "intercultural awareness". Language awareness can be described as "the development in learners of an enhanced consciousness of and sensitivity to the forms and functions of language" (Carter 2003, 64). Intercultural awareness refers to the abilities of self-monitoring and decentring (analysing situations from perspectives other than one's own). Decentring requires both empahy and cultural empathy. Moreover, the metacognitive aspect of cultural empathy can be referred to as "cultural metacognition" and "metaknowledge of culture". According to researchers working with intercultural intelligence,

cultural metacognition increases intercultural effectiveness by promoting (a) contextualized thinking (i.e., heightened sensitivity to the fact that individuals' motivations and behaviors are invariably shaped by the cultural contexts in which they are embedded) and (b) cognitive flexibility (i.e., discriminative use of mental schemas and behavioral scripts when interacting across cultures).

(Chua, Morris, and Mor 2012, 2)

Cognitive flexibility refers to "the ability to deploy cultural knowledge flexibly so that an individual may meet shifting cultural demands and achieve his or her valued goal in the intercultural environment" (Klafehn, Banerjee, and Chiu 2008, 320). Such cultural metacognition can be enhanced by indepth studies of other contexts. By learning about history and society from the perspective of other people, we may learn to switch cultural frames by knowing more about their cultural references. This can also be described as meta-knowledge of cultural impact in that environment. In my interpretation, this means that we can benefit from learning what people in other countries have learnt about their history and society. This adaption of other people's cultural references can also be called secondary knowledge of culture (knowledge of the knowledge other people hold). According to Leung, Lee, and Chiu (2013), "[m]eta-knowledge of culture supports cross-cultural competence because it provides cognitive support to discriminative application of cultural expertise by correcting the biases ensued from overgeneralized primary knowledge of culture" (995). Meta-knowledge of culture can 
in turn become metacognitive when it is based on or developed along with an awareness and monitoring of the shifting of frames, which is what I refer to as cultural empathy.

\section{The Choice of Content Knowledge to Be Included in Courses}

The aspect of knowledge in the model above can be an inspiration for course instructors in need of finding relevant literature to provide students with content knowledge about the development of intercultural competence. Although there will never be one definitive set of relevant topics for developing intercultural competence, it must be a fair assumption that teacher education students would benefit from including topics from the field of intercultural communication in the curriculum. "Intercultural communication" here refers to the interdisciplinary study that often regards scholars, such as the anthropologist and social scientist Gregory Bateson, the anthropologist Edward T. Hall, the linguist Benjamin Whorf and the anthropologist-linguist Edward Sapir, among their founding fathers (see Martin, Nakayama, and Carbough 2014, 18).

Intercultural communication can be difficult to describe as one field of study, as it draws on a number of other fields, such as social anthropology, cultural studies, sociology and cross-cultural psychology. However, rather than being a mere mix of these fields, intercultural communication is a separate field of study that tries to answer the question of how people understand one another when perceptions are distinct enough to alter the communication event (see Lustig and Koester 2006, 52; Samovar, Porter, and McDaniel 2010, 12). Intercultural communication typically incudes topics such as verbal communication, non-verbal communication, value dimensions, stereotypes, prejudice and time orientations (see Samovar et al. 2015, 2017). Course instructors could use such a "package" of topics, recognised as relevant by researchers in the field of intercultural communication, to provide language teacher education with a coherent basis for intercultural learning.

\section{Bridging the Gap between the Field of Intercultural Communication and Language Educators}

Researchers and educators who take the study of intercultural communication as a starting point are sometimes referred to as interculturalists. However, this approach to the development of intercultural competence still does not seem to be fully integrated in language education. Smith, Paige, and Steglitz (2003) write that they " 'have long felt there was a need to bridge the gap between these two fields; interculturalists and language educators have paid insufficient attention to each other's work ...” (89). Fortunately, there seems to be an increasing number of good examples of an integrated approach. The different traditions of interculturalists and language 
educators are represented in the SAGE Handbook of Intercultural Competence (Deardorff 2009a) and The Routledge Handbook of Language and Intercultural Communication (Jackson 2014). With regard to course design, there are also examples of a full integration of the interculturalist perspective in a language education course, such as can be seen in the master's programme, English Foreign Language Education, at the Norwegian University of Science and Technology (see NTNU 2016).

\section{Examples of Teaching Techniques for Metacognitive Reflection}

Obviously, there are numerous ways for a course instructor to enhance metacognitive intercultural learning. As implied in this chapter, a holistic and coherent approach to course design and instruction can be a good starting point. Furthermore, there will be a need for exploring the use of certain teaching techniques that are particularly suitable for metacognitive reflection. In this section, the use of critical incidents and the study of target countries will be discussed.

\section{Critical Incidents and Value Dimensions}

Critical incidents have been suggested as an approach to both teaching and assessment in foreign language education (see Sercu 2004, 74), but it may not be very commonly used. In commercial intercultural training, however, it is a well-known technique. Traditional "critical incidents" are short descriptions incidents in which communication between two people, representing different nationalities, leads to some form of misunderstanding. This follows an introduction to theories of cultural dimensions and orientations, such as Hofstede's original four value dimensions, which were originally introduced in his book Culture's Consequences: International Differences in Work-Related Values (1980): "from high to low power distance", "from individualism to collectivism", "from high to low uncertainty avoidance" and "from masculinity to femininity". Other examples are the scales "from monochronic to polychronic time orientation" and "from direct to indirect communication", inspired by Hall's theories of time and context (Hall 1959, 1976), and the concept of "face" introduced by Brown and Levinson (1978) to describe the degree to which people need to save (their own and others') face in various situations. Renowned commercial intercultural training companies, such as Cultural Awareness International, use such dimensions or scales along with critical incidents as a training procedure. This is no proof of effective learning as such, but it indicates that the use of critical incidents is perceived as a very useful teaching and assessment technique.

However, there are both ontological and pedagogical reasons why this approach to culture can be problematic. Cultural dimensions are often associated with a functionalist or essentialist view of culture, which arguably 
is not a paradigm shared by most scholars in intercultural communication or teacher education today. Correspondingly, cultural dimensions can be perceived as a static approach to communication because there is too much focus on cultural background (see Hofstede 1980) and not on what people actually can do to understand each other when they communicate. Similarly, these dimensions can be interpreted as claiming certainty about general beliefs and values held by people in a national culture (see Holliday 2011, 4). Moreover, scores for particular countries on cultural dimensions can be used in a deterministic way to make predictions about the mindsets and communication patterns of individuals. A constructivist approach to communication, on the other hand, would be more dynamic and focus on what people can achieve together, regardless of background.

As such, this does not mean that cultural dimensions or orientations cannot be used as a dynamic approach to intercultural communication. Hofstede, Pedersen, and Hofstede (2002) underscore that value dimensions are synthetic culture profiles, or extreme manifestations of both ends of the dimensions (91). As they write, "they do not exist in the real world, although the tendencies they demonstrate do exist" (91). For example, a critical realist point of view-combining a constructivist epistemology and a realist ontology — can be used for a metacognitive approach to these tendencies. There is a big difference between claiming certainty about national cultures and pointing to certain tendencies. By studying, comparing and reflecting on tendencies in any society, it should be possible to learn more about the general "mechanisms" (see Bhaskar 2011,19) of intercultural communication and develop intercultural competence within a transnational paradigm.

Nevertheless, there are many good reasons for not using critical incidents in this traditional way. From the course instructor's perspective, there is no need to risk ontological controversies in teacher education, or inadvertently end up with incoherence between the understanding of "intercultural competence" and teaching methods. The most critical aspect of using such incidents, however, can be that there will always be the risk of some students creating or reinforcing stereotypes. In my experience, students often end up stating that "the Japanese are" like this or the "French are" like that. They may describe relevant tendencies, but without any acknowledgement of the complexity or cultural impact. The question is whether there would be a better and non-essentialist approach to critical incidents. Furthermore, even if the analysis of critical incidents between different nationalities could lead to metacognitive intercultural competence, does this type of critical incident actually represent a detour?

\section{Introducing Culture-General Critical Incidents and Role Play}

Contrary to common practice, there should in fact be no need to link exercises to specific nationalities or groups of people. In the case of critical incidents, role play or case studies, the characters should be assigned 
different characteristics, such as direct or indirect communication patterns, regardless of their nationality or group identity. Since communication is always a matter of interaction between human beings, information about their cultural background can very well become a distraction. Alternatively, the people involved in role play or the like could be assigned the same cultural background. Compared to other tools, including the Autobiography of Intercultural Encounters (Council of Europe 2014), this culture-neutral approach to critical incidents or role play underscores the fact that the skills gained from such activities are generic and culture-general. It is not about how to relate to the Japanese or the French, or to people associated with ethnic groups other than one's own, but rather how to relate to any person with a more indirect or direct communication style than one's own. Instead of going through generalised or stereotypical culture-specific characteristics in the hope of developing culture-general skills, a culture-general approach is used to develop culture-general skills.

\section{Introducing Individualised Relativisation Scales}

If the training exercises are culture-general, it seems incoherent to use the original cultural dimensions and orientation-such as Hofstede's value dimensions-for analysis. Therefore, the concept of cultural dimensions scales can be adapted to what I will label more general individual relativisation scales. ${ }^{1}$ As stated above, a lot of research has been done on various concepts and dimensions that seem to represent relevant aspects of mindsets and communication patterns, such as scales from high to low power distance and from direct to indirect communication (Hofstede 1980). These are very useful concepts that can be applied to any interaction, regardless of national cultural background. Instead of being dimensions and scales of national cultures, they can be transformed into scales of human interaction. This could be explored as a central cognitive tool for helping teacher students develop the skill of decentring and changing perspectives, almost literally along a scale. Relativisation or the ability to decentre is acknowledged as a key concept in intercultural learning (see Byram 1997, 34, 42). Decentring is not least related to the concept of adaptability (see Kim 2014, 231), which is a regarded as a central component of intercultural competence by intercultural experts (see Ibid., 231).

Working with dimensions or scales can be highly relevant in language teacher education for many reasons. A good place to start could be relativisation scales that are related to the use of language, or verbal communication, such as "from direct to indirect communication", "from high intensity to low intensity communication" and "from formal to informal communication". For example, on a scale from direct to indirect communication, the objective is to identify one's own communication style in relation to one's interlocutors. This is a very dynamic process of analysis, and even with the same people involved in interaction, it can vary across contexts and topics 
whose style is more or less direct. The more direct person in a given situation will always run the risk of insulting the other person, whereas the more indirect person can risk never getting the message across to the interlocutor.

Equally importantly, individual relativisation scales can be explored as a tool for developing the metacognitive skills of monitoring and consciously regulating the cognitive process of adjusting both the way of thinking and communication behaviour. According to Deardorff (2004), “[c]onsciousness of communicators specifically includes objective self-awareness, selfconsciousness, self-monitoring and interaction involvement" (34). Here too, the overall aim is an awareness of the complexity of communication and culture. As Latour (2005) writes, "[r]elating to one group or another is an ongoing process made up of uncertain, fragile, controversial, and ever-shifting ties" (28). Students should learn to accept plurality and multiperspectivity with regard to both each individual and society in general. Repeated use of relativisation scales in the analysis of case studies and observations can scaffold the decentring process and increase emotional distance if a critical incident or uncertainty should occur in real life; for example, when faced by puzzling behaviours or opinions.

\section{Metacognitive Target-Culture Studies}

It may seem paradoxical, but more culture-general teaching techniques and a transnational paradigm does not mean that a culture-specific approach to target-culture countries should be excluded from a language teacher course or programme. It is common to use literature for the purpose of intercultural learning, but the study of specific national cultures seems to be somewhat more controversial. According to Kelly, an "important issue that remains under discussion is how far the cultural dimension of language learning contributes to intercultural learning" (Kelly 2014, 413). For partly the same reason, there is also one aspect of Byram's model of intercultural communicative competence that seems to have become increasingly controversial, namely his "clear line between our culture and their culture" (Holliday 2011, 19). According to Holliday, this derives "from a strong association between learning a foreign language and a foreign culture" (Holliday 2011, 19; see also Baker 2012, 65). As Byram (1997) writes:

the introduction to the national culture of a country where the language is spoken natively can serve as an example, but must be combined with developing in learners the methods to cope with other situations, based on this example. This supports the argument for a focus on methods, as well as content.

Such a study of national cultures can be conceptually very problematic, but as illustrated in the discussion of "culture" above, the solution can be to sort 
out different concepts and keep them apart. Thus, expressions such as "our culture" and "their culture" should be avoided because they can lead to both stereotyping and othering, which can be described as distancing other people from one's own group. This is partly what Billig (1995) refers to as "banal nationalism" (6). This does not mean, however, that the learning of a foreign language needs to be dissociated from learning about a specific foreign national culture.

I would, in fact, argue that it might be time for a metacognitive "revival" of this tradition of focusing on cultural groups and countries as a teaching technique and not least a way of inspiring students to learn a language. However, very superficial introductions to target countries may not lead to much intercultural learning. One way of avoiding stereotyping and othering can very well be to integrate in-depth studies of specific target countries in teacher education language courses. This form of culture studies, or culture-specific approach, is known to many course instructors as, for example, civilisation (English, French) or Landeskunde (German). As Holliday (2011) also acknowledges, nations should be recognised as significant ideological forces (13). This can be a god starting point for studying cultural impact in general. However, students should be exposed to the difference between the concept of national culture and cultural impact at the individual level, as well as a meta-knowledge of culture and the general aim of cultural empathy (see Figure 4.1 and the discussion of the components of intercultural competence above).

\section{Assessment of Intercultural Competence}

The steps taken above-defining concepts and identifying learning aimsare premises for assessment (see Deardorff 2015, 131). Still, finding good assessment instruments is not an easy task (see Perry and Southwell 2011, 460; Sercu 2010, 17-31). Discussing learning outcomes in higher education, Deardorff $(2009 b)$ writes that "there is often much confusion and anxiety as to how to implement actual assessment of intercultural competence" (477). This does not mean that it cannot or should not be done. First of all, there is the "backwash effect", which means that assessment will encourage learning (see Sercu 2010, 20). Second, assessment can give educators in teacher education feedback on the effectiveness of intercultural learning and help researchers refine and develop theories of intercultural competence (see Perry and Southwell 2011, 459). Most importantly, however, students should be assessed in order to foster further development. This may, for example, involve what Borghetti (2015) refers to as "dynamic assessment" in accordance with Vygotsky's Sociocultural Theory (3). External support from the instructor or others may be crucial for making students take further steps.

Also with regard to assessment, delimitations are necessary. As Deardorff $(2009 b)$ writes: "Since assessing the whole of intercultural competence is 
a daunting task, it is recommended to prioritize specific aspects of competence, based on the overall mission and purpose of the course, program, or organization" (481). One example is an assessment sheet based on intercultural competence models developed by Deardorff (2015). Here, students are asked to rate themselves on a scale from one to five with regard to 15 essential components of intercultural competence, such as "openness", "flexibility (in using appropriate communication patterns and behaviours in intercultural situation)", "cultural self-awareness/understanding", "skills to analyse, evaluate, and relate" and communication skills (appropriate and effective communication in intercultural settings) (145). Second, the students are asked to:

Reflect on situations requiring intercultural competence. What helped make you more appropriate and effective in your interactions? Now reflect on how you can continue to develop your intercultural competence, especially areas you rated lower.

Such reflection focuses on metacognition, regarding both "(a) knowledge of cognition and (b) the processes involving the monitoring, control, and regulation of cognition" (Pintrich 2002, 219). Particularly the second aspect seems to be important for developing conscious strategies for adapting to novel situations in shifting contexts in the future. This can also be referred to as metacognitive strategies, defined as "general skills through which learners manage, direct, regulate, guide their learning, i.e. planning, monitoring and evaluating" (Wenden 1998, 519).

There are also numerous other instruments (see Fantini 2009, 466-77), including the Council of Europe's Framework of Reference for Pluralistic Approaches to Languages and Cultures (FREPA) (Council of Europe 2012). In this framework, the competence of decentring is intended to activate knowledge, skills and attitudes through reflection and action. Another tool that is increasingly used in teacher education (see Cushner and Mahon 2009,310 ) is the Intercultural Development Inventory (IDI), developed by Hammer, Bennet, and Wiseman (2003). Based on Bennet's (1986) development model of intercultural sensitivity, the level of intercultural sensitivity is assessed along a scale from highly ethnocentric to highly ethnorelative.

Even better known might be the Autobiography of Intercultural Encounters (Council of Europe 2014), which is mentioned above, and the INCA project: Intercultural Competence Assessment (European Commission 2009). As Sercu (2010) points out, however, linking the development of intercultural competence to actual encounters is problematic (31). In educational settings, many students do not have much experience, and the focus on actual encounters may suggest that intercultural competence cannot be developed in educational settings as well. For that reason, the teaching techniques of culture-general incidents and individual relativisation scales 


\section{Magne Dypedahl}

described above may also be explored further as assessment tools. Observing, discussing and analysing such incidents will not rely solely on experience. Metacognitive intercultural learning can be encouraged, for example, by letting students reflect on the communication of others in critical incidents or their own communication in recorded or filmed role plays. This means that they can be helped to consciously monitor and regulate their own thinking and behaviour, which make up an important part of their intercultural awareness.

\section{Conclusion}

There is little doubt that metacognitive skills can be taught (see Lane 2009, 130). The same is true for a metacognitive approach to the development of intercultural competence. However, it can be challenging to develop the metacognitive aspects, or any other aspects, of intercultural competence without conceptual coherence, clarity and explicitness. In my view, the measures for more focus on metacognition in intercultural learning outlined above can be a contribution to helping language teacher students develop their capacities as intercultural learners and teachers. One suggestion in this chapter is to classify intercultural awareness as one component of intercultural competence, and not as one of the synonyms of intercultural competence, in order to make the metacognitive aspect of intercultural competence more tangible. Furthermore, both the culture-general approach to cultural dimensions-individual relativisation scales—and in-depth meta-knowledge of target cultures may be new approaches to intercultural learning that could make it more metacognitive. Also, with regard to the assessment, there is good reason for course instructors and researchers to further explore the role of metacognition in intercultural learning in order to avoid endorsing "stereotypes and prejudice against the culturally different 'Other'" (Chao, Okazaki, and Hong 2011, 266). On the contrary, the aim is to ensure an endorsement of multiperspectivity, understanding and tolerance.

\section{Note}

1 The concept of adapting cultural dimensions to the individual level was developed in cooperation with Associate Professor Henrik Bøhn as a result of interesting conversations over many years and cooperation on numerous intercultural training sessions in Norway involving participants representing more than 100 different countries.

\section{References}

Baker, Will. 2012. "From Cultural Awareness to Intercultural Awareness: Culture in ELT.” ELT Journal 66 (1): 62-70. https://doi.org/10.1093/elt/ccr017

Bennett, Milton J. 1986. "Towards Ethnorelativism: A Developmental Model of Intercultural Sensitivity." In Cross-Cultural Orientation: New Conceptualizations 
and Applications, edited by R. Michael Paige, 27-70. New York: University Press of America.

- 1998. "Intercultural Communication: A Current Perspective." In Basic Concepts of Intercultural Communication: Selected Readings, edited by Milton J. Bennett, 1-34. Yarmouth: Intercultural Press, Inc.

Bhaskar, Roy. 2011. Reclaiming Reality: A Critical Introduction to Contemporary Philosophy. London / New York: Routledge.

Billig, Michael. 1995. Banal Nationalism. London: Sage Publications.

Borghetti, Claudia. 2015. "Considerations on Dynamic Assessment of Intercultural Competence." In Diversity, Plurilingualism and their Impact on Language Testing and Assessment, TEASIG Conference Proceedings, Siena 2013, selected articles by the presenters edited by Judith Mader and Zeynep Urkun, 17-20. Kent, UK: IATEFL (TEA SIG). Accessed August 20, 2017. https://core.ac.uk/download/ pdf/53182937.pdf

Bransford, John D., Ann L. Brown, and Rodney R. Cocking, eds. 2000. How People Learn: Brain, Mind, Experience, and School. Washington, DC: National Academy Press.

Brown, Penelope, and Stephen C. Levinson. 1978. "Universals in Language Usage: Politeness Phenomena." In Questions and Politeness: Strategies in Social Interaction, edited by Esther N. Goody, 56-310. Cambridge: Cambridge University Press.

Byram, Michael. 1997. Teaching and Assessing Intercultural Communicative Competence. Clevedon: Multilingual Matters Ltd.

Carter, Ronald. 2003. "Language Awareness.” ELT Journal 57 (1): 64-5. https:// doi.org/10.1093/elt/57.1.64

Chao, Melody Manchi, Sumie Okazaki, and Ying-yi Hong. 2011. "The Quest for Multicultural Competence: Challenges and Lessons Learned from Clinical and Organizational Research." Social and Personality Psychology Compass 5 (5): 263-74. https://doi.org/10.1111/j.1751-9004.2011.00350.x

Chua, Roy Y. J., Michael W. Morris, and Shira Mor. 2012. "Collaborating Across Cultures: Cultural Metacognition and Affect-based Trust in Creative Collaboration." Organizational Behavior and Human Decision Processes 118 (2): 116-31. https://doi.org/10.1016/j.obhdp.2012.03.009

Council of Europe. 2012. "A Framework of Reference for Pluralistic Approaches to Languages and Cultures." Graz: European Centre for Modern Languages. Accessed January 20, 2017. http://carap.ecml.at/

- 2014. "Autobiography of Intercultural Encounters.” Strasbourg: Council of Europe's Language Policy Division. Accessed January 20, 2017. www.coe.int/t/ dg4/autobiography/default_EN.asp.

Cushner, Kenneth, and Jennifer Mahon. 2009. "Developing the Intercultural Competence of Educators and Their Students: Creating the Blueprints." In The SAGE Handbook of Intercultural Competence, edited by Darla K. Deardorff, 304-20. Los Angeles: Sage Publications Inc.

Deardorff, Darla K. 2004. "The Identification and Assessment of Intercultural Competence as a Student Outcome of Internationalizations at Institutions of Higher Education in the United States." PhD diss. Raleigh, North Carolina: North Carolina State University. Accessed October 10, 2016. https://repository.lib.ncsu.edu/ bitstream/handle/1840.16/5733/etd.pdf? sequence=1\&isAllowed=y 
2006. "The Identification and Assessment of Intercultural Competence as a Student Outcome of Internationalization." Journal of Studies in International Education 10 (3): 241-66. https://doi.org/10.1177/1028315306287002

_., ed. 2009a. The SAGE Handbook of Intercultural Competence. Los Angeles: Sage Publications Inc.

- 2009b. "Implementing Intercultural Assessment." In The SAGE Handbook of Intercultural Competence, edited by Darla K. Deardorff, 477-503. Los Angeles: Sage Publications Inc.

-2015. Demystifying Outcomes Assessment for International Educators: A Practical Approach. Stirling: Stylus.

Dypedahl, Magne, and Henrik Bøhn. 2017. Veien til interkulturell kompetanse [The Road to Intercultural Competence]. Bergen: Fagbokforlaget.

Earley, P. Christopher, and Soon Ang. 2003. Cultural Intelligence: Individual Interactions Across Cultures. California: Stanford University Press.

Earley, P. Christopher, Soon Ang, and Joo-Seng Tan. 2006. Developing Cultural Intelligence at Work. California: Stanford University Press

European Commission. 2009. "The INCA Project: Intercultural Competence Assessment.” Accessed April 15, 2017. https://ec.europa.eu/migrant-integration/ librarydoc/the-inca-project-intercultural-competence-assessment

Fantini, Alvino E. 2009. "Assessing Intercultural Competence." In The SAGE Handbook of Intercultural Competence, edited by Darla K. Deardorff, 456-76. Los Angeles: Sage Publications Inc.

- 2014. "Language: An Essential Part Component of Intercultural Communicative Competence." In The Routledge Handbook of Language and Intercultural Communication, edited by Jane Jackson, 263-78. London / New York: Routledge. Flavell, John H. 2004. "Theory-of-Mind Development: Retrospect and Prospect." Merrill-Palmer Quarterly 50 (3): 274-90. https://doi.org/10.1353/mpq.2004.0018 Hall, Edward T. 1959. The Silent Language. Garden City: Anchor Press.

. 1976. Beyond Culture. Garden City: Anchor Press.

Hammer, Mitchell R., Milton J. Bennett, and Richard Wiseman. 2003. "Measuring Intercultural Sensitivity: The Intercultural Development Inventory." International Journal of Intercultural Relations, 27, 421-43. https://doi.org/10.1016/ S0147-1767(03)00032-4

Haukås, Åsta. 2018. "Metacognition in Language Learning and Teaching: An Overview.” In Metacognition in Language Learning and Teaching, edited by Åsta Haukås, Camilla Bjørke, and Magne Dypedahl. New York: Routledge.

Hofstede, Geert. 1980. Culture's Consequences: International Differences in WorkRelated Values. Beverly Hills: Sage Publications.

Hofstede, Gert Jan, Paul B. Pedersen, and Geert Hofstede. 2002. Exploring Culture: Exercises, Stories and Synthetic Cultures. Boston/London: Intercultural Press.

Holliday, Adrian. 2011. Intercultural Communication and Ideology. London: Sage Publications.

Jackson, Jane, ed. 2014. The Routledge Handbook of Language and Intercultural Communication. London / New York: Routledge.

Jensen, Iben. 2011. "Postkulturell kommunikation-fordi kultur ikke alltid er vigtigst [Post-cultural Communication-Because Culture Is Not Always the Most Important Thing]" In Forståelsens gylne Øyeblikk: festskrift for Øyvind Dabl [The Golden Moment of Understanding; Commemorative Publication for Øyvind 
Dahl], edited by Tomas Sundnes Drønen and Marianne Skjortnes, 47-61. Trondheim: Tapir Akademisk Forlag.

Kelly, Michael. 2014. "Second Language Teacher Education." In The Routledge Handbook of Language and Intercultural Communication, edited by Jane Jackson, 409-21. London/New York: Routledge.

Kim, Young Yun. 2014. "Beyond Cultural Categories." In The Routledge Handbook of Language and Intercultural Communication, edited by Jane Jackson, 229-43. London/New York: Routledge.

Klafehn, Jennifer, Preeta M. Banerjee, and Chi-yue Chiu. 2008. "Navigating Cultures: The Role of Metacognitive Cultural Intelligence." In Handbook of Intercultural Intelligence: Theory, Measurement, and Applications, edited by Soon Ang and Linn Van Dyne, 318-31. Amonk: M.E. Sharpe Inc.

Lane, H. Chad. 2009. "Promoting Metacognition in Immersive Cultural Learning Environments.” In Human-Computer Interaction, Part IV, edited by Julie A. Jacko, 129-39. Berlin/Heidelberg: Springer Verlag.

Latour, Bruno. 2005. Clarendon Lectures in Management Studies: Reassembling the Social: An Introduction to Actor-Network-Theory. Oxford: University of Oxford Press.

Leung, Angela K.-Y., Sau-lai Lee, and Chi-yue Chiu. 2013. "Meta-Knowledge of Culture Promotes Cultural Competence.” Journal of Cross-Cultural Psychology 44 (6): 992-1006. https://doi.org/10.1177/0022022113493137

Leung, Kwok, Soon Ang, and Mei Ling Tan. 2014. "Intercultural Competence." The Annual Review of Organizational Psychology and Organizational Behavior 1: 489-519. https://doi.org/10.1146/annurev-orgpsych-031413-091229

Lustig, Myron W., and Jolene Koester. 2006. Intercultural Competence: Interpersonal Communication Across Cultures. 5th ed. Boston: Pearson.

Martin, Judith N., Thomas K. Nakayama, and Donal Carbough. 2014. "The History and Development of the Study of Intercultural Communication and Applied Linguistics." In The Routledge Handbook of Language and Intercultural Communication, edited by Jane Jackson, 17-36. London/New York: Routledge.

Norwegian University of Science and Technology (NTNU). 2016. Pensumliste Var 2016, Masterprogram ved program for loererutdanning: Master i fag-og yrkesdidaktikk og loererprofesjon [Reading List Spring 2016, Master's Programme for Teacher Education: Master of Science in Didactics]. Accessed November 20, 2016. www.ntnu.no/documents/10434/1266803142/MFAGD_V16_Pensumliste. pdf/b1661a43-989b-4432-86ce-385d02987af8

Perry, Laura B., and Leonie Southwell. 2011. "Developing Intercultural Understanding and Skills: Models and Approaches.” Intercultural Education 22 (6): 453-66. https://doi.org/10.1080/14675986.2011.644948

Peterson, Brooks. 2004. Cultural Intelligence: A Guide to Working with People from Other Cultures. Boston/London: Intercultural Press.

Pintrich, Paul R. 2002. "The Role of Metacognitive Knowledge in Learning, Teaching and Assessing.” Theory Into Practice 41 (4): 219-25. https://doi.org/10.1207/ s15430421tip4104_3

Risager, Karen. 2007. Language and Culture Pedagogy: From a National to a Transnational Paradigm. Clevedon: Multilingual Matters.

Samovar, Larry A., Richard E. Porter, and Edwin R. McDaniel. 2010. Communication Between Cultures. 7th ed. Boston: Wadsworth Cengage Learning. 
Samovar, Larry A., Richard E. Porter, Edwin R. McDaniel, and Carolyn S. Roy, eds. 2015. Intercultural Communication: A Reader. 14th ed. Boston: Wadsworth Cengage Learning.

- 2017. Communication Between Cultures. 9th ed. Boston: Wadsworth Cengage Learning.

Sercu, Lies. 2004. "Assessing Intercultural Competence: A Framework for Systematic Test Development in Foreign Language Education and Beyond.” Intercultural Education 15 (1): 73-88. https://doi.org/10.1080/1467598042000190004

_. 2010. "Assessing Intercultural Competence: More Questions than Answers." In Testing the Untestable in Language Education, edited by Amos Paran and Lies Sercu, 17-34. Bristol, Buffalo and Toronto: Multilingual Matters.

Shaffer, Margaret A., and Gloria J. Miller. 2008. "Cultural Intelligence: A Key Success Factor for Expatriates." In Handbook of Cultural Intelligence: Theory, Measurement, and Applications, edited by Soon Ang and Linn Van Dyne, 107-25. Amonk: M.E. Sharpe, Inc.

Smith, Shirley L., R. Michael Paige, and Inge Steglitz. 2003. "Theoretical Foundations of Intercultural Training and Applications to the Teaching of Culture." In Culture as the Core: Perspectives on Culture in Second Language Learning, edited by Dale L. Lange and R. Michael Paige, 89-125. Greenwich: Information Age Publishing.

Spitzberg, Brian H., and Gabrielle Changnon. 2009. "Conceptualizing Intercultural Competence." In The SAGE Handbook of Intercultural Competence, edited by Darla K. Deardorff, 2-52. Los Angeles: Sage Publications Inc.

Van de Vijver, Fons J. R., and Kwok Leung. 2009. "Methodological Issues in Researching Intercultural Competence." In The SAGE Handbook of Intercultural Competence, edited by Darla K. Deardorff, 404-18. Los Angeles: Sage Publications Inc.

Van Dyne, Linn, Soon Ang, and Christine Koh. 2008. "Development and Validation of the CQS: The Cultural Intelligence Scale." In Handbook of Cultural Intelligence: Theory, Measures and Applications, edited by Soon Ang and Linn Van Dyne, 16-38. Armonk: M.E. Sharpe.

Wenden, Anita L. 1998. "Metacognitive Knowledge and Language Learning." Applied Linguistics 19 (4): 515-37. https://doi.org/10.1093/applin/19.4.515

Williams, Raymond. 1983. Keywords: A Vocabulary of Culture and Society. Rev. ed. New York: Oxford University Press. 